\title{
Antiangiogenesis: Current Clinical Data and Future Perspectives
}

\author{
J. Drevs* \\ C. Laus* \\ M. Medinger \\ C. Schmidt-Gersbach \\ C. Unger
}

Klinik für Tumorbiologie, Freiburg

\section{Key Words}

Antiangiogenesis - Angiogenic phenotypes - Preclinical studies - Clinical studies - Metronomic therapy

\section{Summary}

Neovascularization is a prerequisite for progressive growth of solid tumors and their metastases. This process is tightly regulated by a large number of proangiogenic and antiangiogenic factors such as VEGF, bFGF and matrix-metalloproteinases. The inhibition of angiogenesis is an innovative therapeutic approach and could represent a powerful adjunct to traditional therapy of malignant tumors. Preclinical trials have been very successful but in clinical studies meaningful response rates could only be shown in some cases. This might indicate the existence of different angiogenic phenotypes in humans. It seems that at present only a part of the interactions between the angiogenic cytokines are known. In addition, new receptor/ligand systems which regulate the neovascularization are being described. This article presents an overview of the most important angiogenically active substances, preclinical and clinical data, surrogate markers as well as future perspectives.

\section{Introduction}

Malignant tumors are not primarily integrated in the existing vessel system so that nutrients acquired through diffusion are not substantial enough for progressive neoplasm and metastasis growth above a few $\mathrm{mm}$ in diameter. Thus, a connection to the body's nutritive system is essential for growth and spread. Angiogenesis usually occurs primarily during the embryonic

* Both authors contributed equally to this work.

\section{Schlüsselwörter}

Antiangiogenese · Angiogener Phänotyp · Präklinische Studien · Klinische Studien · Metronomische Therapie

\section{Zusammenfassung}

Voraussetzung für das progressive Wachstum von soliden Tumoren und deren Metastasen ist die Neovaskularisierung. Die Regulierung dieses Prozesses erfolgt durch Wachstumsfaktoren, zu denen unter anderem VEGF, bFGF und die Metalloproteinasen gehören. Die Angiogenesehemmung stellt einen innovativen Therapieansatz zur Behandlung von malignen Tumoren dar. Präklinische Untersuchungen sind sehr erfolgreich verlaufen, in klinischen Studien konnten jedoch bislang nur in einigen Fällen bedeutsame Ansprechraten gezeigt werden. Dieses könnte auf das Vorliegen von verschiedenen angiogenen Phänotypen beim Menschen hindeuten. Offensichtlich sind die vielfältigen Interaktionen zwischen den angiogen wirksamen Zytokinen erst zum Teil bekannt. Noch immer werden zudem neue Rezeptor-Ligandensysteme beschrieben, die regulierend in die Neovaskularisierung eingreifen. Der Artikel gibt eine Übersicht über die wichtigsten angiogen aktiven Substanzen, präklinische und klinische Daten, verwendete Surrogatmarker sowie Zukunftsaussichten.

development. In adults it is quiescent, becoming locally and transiently activated for its involvement in the physiological processes of the female reproductive cycle, hair-growth, and wound healing. In malignant tumors the development and spread of new capillaries (neovascularization) is directed and regulated by a complex network of mechanisms which control tumor angiogenesis via positively and negatively effective angiogenic factors. This implies that the physiological balance which usually exists between oncogens (positive angiogenic factors) and tumor suppressors (negative angiogenic factors) 
is disturbed. Alongside genetic changes during tumorgenesis oncogens are activated and tumor suppressors are inactivated, which leads to an overexpression of proangiogenic cytokines and a loss of the protective effects of the tumor suppressor genes (e.g. p53) in cancer cells. This is commonly termed the angiogenic switch.

Once a tumor has been invaded by blood vessels, the solid mass is supplied with oxygen and an exchange of metabolites occurs. Neovascularization can be further stimulated by factors being secreted by the tumor. These 'leaky' vessels enable the tumor to metastasize via the vascular system to various sites.

The inhibition of angiogenesis is a promising new therapeutic strategy for the medical treatment of malignant tumors. In contrast to conventional therapies, antiangiogenic therapy does not aim to directly destroy or remove the tumor, but to prevent growth by blocking the supply of nutrients and the removal of metabolites.

As a common cell type to all solid tumors, endothelial cells represent a preferential target for antiangiogenic cancer therapy. An acquired drug resistance against antiangiogenic drugs is not expected due to the genetic stability of endothelial cells in contrast to the rapidly mutating, genetically unstable cancer cells. Furthermore, no severe toxicities are expected. Therefore, new diagnostic tools are necessary to assess biological activity of each compound to define the optimal dose. This is in striking contrast to treatment with cytotoxic compounds that are used at the maximal tolerable dose (MTD).

The block of tumor growth by antiangiogenesis requires a chronic inhibition of vascular recruitment so that a long-term treatment is necessary and an oral administration of drugs is recommended.

There is a great diversity of drugs and corresponding molecular targets which can influence angiogenesis. They can be subdivided into several categories such as endogenous proangiogenic factors, endogenous inhibitors, unspecific endothelial cell inhibitors and inhibitors of communication between endothelial and mesenchymal cells. The most important of these factors as well as the surrogate markers used to assess their biological activity will be presented in the following article.

\section{Most Relevant Proangiogenic Factors}

VEGF (vascular endothelial growth factor) is known as one of the most important regulators of angiogenesis. The biological effects on vessels are mediated by two specific receptors, KDR and flt- 1 . These receptors are mainly expressed on proliferating endothelial cells. Neovascularization is stimulated directly by an increase in proliferation and migration of the endothelial cells, and indirectly due to hyperpermeabilization of the vessels. The latter leads to a release of plasma proteins, which in turn generates an adequate environment for new vessel growth. VEGF is produced by tumor cells, the expression in tumors is upregulated in comparison to that of normal tis- sue [1]. Several VEGF antagonists have been developed which have lead to very promising results in vitro and in animal models. It could be shown that inhibitors are able to greatly reduce the size of tumors and the number of vessels. The VEGF-antibody HuMV and the small molecular-weight inhibitors of the VEGF2 (KDR) receptor tyrosine kinase, PTK787/ZK22254 and SU 5416, belong to the most effective substances [2-4]. The newer substances, like SU 6668 and ZD6474, are VEGF, FGF (fibroblast growth factor) and PDGF (platelet derived growth factor) receptor tyrosine kinase inhibitors [5,6]. Caused by their multiple inhibition properties of other proangiogenic factors it was shown that a higher antiangiogenic effect is the result, although the risk of side effects might increase.

\section{Most Relevant Antiangiogenic Factors}

Angiostatin (a $38 \mathrm{kDa}$ plasminogen fragment) and endostatin (a collagen XVIII fragment) are endogenous inhibitors of angiogenesis, inhibiting ATP synthase and thus preventing endothelial cell proliferation. For quite a long time specific receptors as well as the signal transduction pathway for these factors could not be identified.

Recently however, the inhibitory effect of endostatin on MMP (matrix metalloproteinase) activation from proMMPs as well as integrins has been described as a possible mechanism. Excellent results with complete tumor regression could be shown in animal models, where, remarkably, even after several cycles the animals did not develop resistance to the therapy and no new tumor growth occurred after therapy termination $[7,8]$. Thrombospondin-1 (TSP-1) is expressed by blood platelets as well as many other cells. Alongside its various defined functions, it is also known to have an antiangiogenic effect. The so-called type-one repeats and, to a lesser extent, the procollagen-homology-region (both being TSP subunits) are responsible for the antiangiogenic effect of TSP-1 and are mediated by the CD36 receptors on the microvascular endothelial cells. Both TSP and the type-one-repeat fusion proteins have shown strong antiangiogenic activity in vitro and in animal models [9].

\section{Cell-Cell Interaction in Angiogenesis}

The matrix-metalloproteinases (MMPs) are a group of more than 20 enzymes. They have the ability to degrade components of the extracellular matrix, which is a prerequisite for the proliferation of tumor cells and neovascularization. A physiological balance exists between MMPs and TIMPs (tissue inhibitors of MMPs). In tumor stroma cells, but also in tumor cells, overexpression of various MMPs, especially MMP-2 and -9, occurs in comparison to normal tissue. In preclinical studies, MMP inhibitors have been shown to inhibit 
proliferation in tumor cell lines and EC (endothelial cell) lines as well as in animal models [10,11]. A distinction was made between unspecific substances which affect several MMPs and those which especially inhibit MMP-2, -3 and -9. Batimastat, marimastat, AG 3340 (prionomastat) and CGS 27023A are all agents with pleiotropic effect. Neovastat (AE 941), a shark cartilage extract, is also an unspecific MMP-inhibitor, which contains TIMP-like substances. These substances are responsible for part of the effects. A VEGF inhibiting effect has also been described as a further mechanism. BAY 12-9566 and BMS-275291 are examples of more specific second-generation MMP inhibitors which act more selectively against MMP-2, -3 and -9 [12]. COL-3 (Metastat ${ }^{\circledR}$ ) is a tetracycline derivative with a relatively high specificity for MMP-2 and -9 .

The integrins are a group of more than 22 cell-surface glycoproteins, which are composed of alpha and beta chains. These mediate specific molecular interactions between vascular cells and the extracellular matrix and are capable of recognizing the so-called RGD sequence present in their ligands, the extracellular matrix proteins. Integrins are able to distinguish between different proteins in the extracellular matrix due to the specificity of the RGD sequence. As angiogenesis is dependent on specific molecular interactions between vascular cells and the extracellular matrix, it has been concluded that integrins are of functional importance in this process. Although minimal integrin expression takes place on normal blood vessels, a significantly higher expression can be found on tumor blood vessels. The $\alpha v \beta 3$ and $\alpha v \beta 5$ integrins play a critical role in angiogenesis. FGF- and VEGF-induced cell proliferation could be blocked in vitro. Several inhibitors are known: Vi$\operatorname{taxin}^{\circledR}$ (LM 609), a monoclonal anti- $\alpha v \beta 5$ antibody, Sch 221153, a small-molecular-weight peptide which antagonizes $\alpha v \beta 3$ and $\alpha v \beta 5$ and EMD 121974, an $\alpha v \beta 3$ inhibitor [13-15]. All of these substances have shown an antiangiogenic effect in vitro and in animal models.

\section{Clinical Studies}

After several antiangiogenic substances were extremely successful in vitro and in animal models, many drugs are currently being evaluated in classical phase I-III clinical studies (table 1). In addition, different techniques are used as surrogate markers to assess biological activity that might occur below the MTD and might define the optimal dose.

\section{Inhibition of Proangiogenic Cytokines}

PTK787/ZK22254, a small-molecular-weight antagonist of the VEGF receptor KDR, is one of the first antiangiogenic substances to be tested in clinical studies in Germany. This compound is studied in patients with solid tumors and glioblastoma in different phase I studies. Stable disease (SD) up to 15 months could be recorded in approximately half of the patients, mainly with colorectal and breast cancer. Best respons- es observed were minor responses (MR). Dose-limiting toxicity did not occur up to a dose of 2,000 mg/d. The most common side effects like ataxia and worsening of preexisting hypertension were reversible. Having investigated the detection of serum levels of soluble proangiogenic factors, of tumor blood flow by color Doppler imaging and of tumor permeability by dynamic contrast-enhanced magnetic resonance imaging (dceMRI) as surrogate markers to detect biological activity, the optimal dose of PTK787/ZK222584 was defined at $1,200 \mathrm{mg} / \mathrm{d}$. The studies are ongoing and a phase II/III study is planed after completion of phase I [16].

$S U$ 5416, another VEGF receptor antagonist, is presently being tested on patients with advanced tumors in several phase I-III studies. A phase I study had already shown clinical activity in NSCLC (non-small cell lung cancer). From 8 patients in a phase II study on patients with malignant melanoma, 1 showed SD and 1 PR (partial remission). Toxicity consisted of diarrhea, allergic reactions, and fatigue. The optimal dosage was found to be $145 \mathrm{mg} / \mathrm{m}^{2}$ twice a week [17]. One disadvantage of this substance is the i.v. formulation. Therefore, a further phase I study is being carried out in order to test oral bioavailability. Preliminary data are promising. So far, the use of positron emission tomography (PET) and intravital microscopy did not result in any detection of biological activity. Several studies in which SU 5416 is applied in combination with various chemotherapies or immunotherapies are not yet completed. Preliminary data do not show increased toxicity in comparison with chemotherapy alone.

Pfizer is developing CP-547.632, a novel isothiazole selective for KDR inhibition. CP-547.632 is orally bioavailable, welltolerated, and is currently in phase I trials in cancer patients. Preliminary human pharmacokinetics data in advanced cancer patients were recently disclosed: 24 patients receiving oral administration of CP-547.632 at $35 \mathrm{mg}$ for 14 days to $160 \mathrm{mg}$ per day continuously for a median of 2 courses (range 1-7) [18]. Half-life was estimated to be 29 h. No dose-limiting toxicity or treatment discontinuations were observed in either of the dose cohorts except for a transient non-maculopapular rash and dry mouth observed in 2 of 24 patients. Disease stabilization was observed in 6 of 22 evaluable patients.

Sporadic incidences of SD with low toxicity could be recorded within a continuing phase I study with orally applied ZD 6474, a VEGF and EGF receptor antagonist [19]. The most relevant toxicities were described as skin rash, QT-prolongation and diarrhea, all possibly related to the EGF-receptor activity.

The newest substance in this group is $S U$ 6668, a multiple tyrosine kinase receptor inhibitor (KDR, PDGF-R, FGF-R1, C-KIT), which can be applied orally. The interim report of a phase I study informed about several patients with SD up to 6 months and one MR. Mild to moderate toxicity occurred in form of fatigue, pleural pain and thrombopenia. Optimal doses described are $1600 \mathrm{mg} / \mathrm{m}^{2} / \mathrm{d}$, and were chosen from pharmacokinetics. The use of proteomic techniques did not result in the detection of biological activity [5]. 


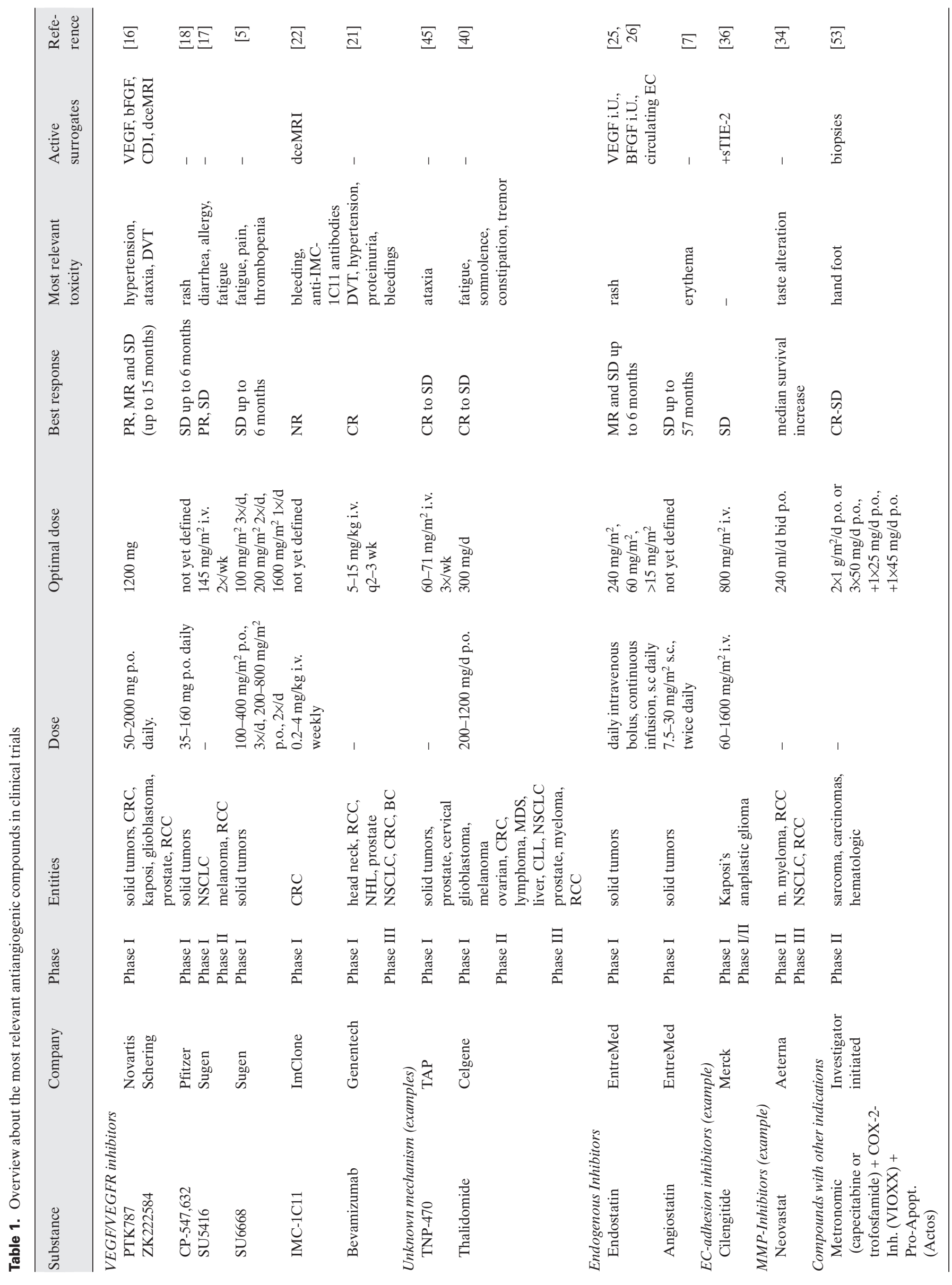


Cephalon is studying CEP-7055, an orally active selective panVEGF receptor kinase inhibitor in Phase I clinical studies [20]. CEP-7055 is the N,N-dimethyl glycine ester pro-drug of CEP-5214, a water-soluble, orally active substituted fused pyrrolocarbazole that inhibits KDR, Flt- 1 and Flt-4 with IC $_{50}$ values of 18,12 and $17 \mathrm{nM}$, respectively.

Anti-VEGF antibody therapy is currently studied in clinical phase I and III studies. For Bevamizumab (Avastin), an antiVEGF antibody used in doses of $5-15 \mathrm{mg} / \mathrm{kg}$ every other week, sporadic cases of SD are described. Deep-vein thrombosis, hypertension, proteinuria, bleedings, cramps and dyspnoe were described as main drug-related side effects [21]. Optimal dose for anti-VEGF-receptor antibody therapy, as studied in phase I trials with $I M C-1 C 11$, is not yet defined, although changes in dceMRI are already described in initial doses of $0.2-4 \mathrm{mg} / \mathrm{kg}$ [22].

\section{Therapeutic Use of Endogenous Antiangiogenic Factors}

Clinical studies have been delayed due to the amount of recombinant endostatin and angiostatin required to induce anti-tumor effects in humans. Meanwhile, phase I studies on patients with various solid tumors are being carried out. First data on endostatin, presented at ASCO 2001, showed that the equivalent doses used in animal models $\left(300 \mathrm{mg} / \mathrm{m}^{2}\right)$ had no effect on the tumors. SD could be shown sporadically; grade III and IV toxicity did not occur [23, 24]. At ASCO 2002, first minor responses and disease stabilization could be reported for angiostatin and endostatin [25, 26]. MTD of endostatin is detected at $240 \mathrm{mg} / \mathrm{m}^{2}$ for daily i.v. and $60 \mathrm{mg} / \mathrm{m}^{2}$ for continuos infusion. Side effects observed (erythema with angiostatin and rash with endostatin) were moderate. Surrogate markers like VEGF and bFGF concentrations in urine as well as circulating endothelial cells, changed under therapy with endostatin indicating biological activity at low doses. In contrast, no changes in dceMRI are described under treatment with angiostatin.

\section{Inhibition of Cell-Cell Interaction in Tumorangiogenesis}

In the past few years a number of phase I-III studies have been carried out using MMP inhibitors. The results of the broad spectrum MMP inhibitors batimastat and marimastat were mainly disappointing. No antitumoral effect could be achieved with a single substance. A longer survival without progression and total survival after marimastat application was recorded in one study on patients with advanced stomach carcinoma [27]. A 75\% response rate was achieved in combination therapies with doxorubicin and docetaxel in patients with advanced breast carcinoma [28]. In other studies, using the same combination in breast cancer patients, response rates of $57-77 \%$ could be observed. Marimastat is currently being used in studies on metastasized tumors (e.g. SCLC) to prevent disease progression after completion of chemotherapy.

In a phase II study on prionomastat with patients with advanced breast cancer, SD could be achieved in 5 of 44 patients
[29]. An additive effect in combination with paclitaxel and carboplatin in comparison to chemotherapy alone in patients with NSCLC could not be observed [30, 31].

Marked muscular-skeletal side effects occurred with the named metalloproteinase inhibitors, especially a dose-limiting inflammatory polyarthritis. The reason for these side effects is obviously high MMP expression in joints. The recommended doses for marimastat and prionomastat are 10 and $25 \mathrm{mg} / \mathrm{d}$. There are as yet no results for CGS 27023 A, also unspecific. Relevant phase I studies are ongoing.

It is assumed that the results of the current studies with the inhibitors BMS 275294 and COL-3, specific against MMP-2 and -9 , will be very promising. MMP-2 and -9 are upregulated in tumors and obviously have an important function in tumor development. Fewer musculoskeletal side effects are expected due to their relatively specific effect [32]. COL-3 is being tested in phase I studies on patients with advanced solid tumors. Preliminary results in patients with non-epithelial malignomas show that SD could be achieved. Phototoxicity and fatigue were dose-limiting factors [33]. No data are available for the response rates with BMS 275291 at present. As expected, no dose-limiting polyarthritis could be recorded in one phase I study. Mild side effects included grade I-II myalgia/athralgia. The recommended dose for further studies is defined as 1,200 $\mathrm{mg} / \mathrm{d}$ for BMS 275291 and $70 \mathrm{mg} / \mathrm{m}^{2} / \mathrm{d}$ for Col-3.

Neovastat is exceptional as an unspecific MMP inhibitor and is at present being tested for the treatment of kidney cancer in phase II studies, as well as multiple myeloma and lung carcinomas in phase III studies. Preliminary data could show a significant increase in median survival describing taste alterations as side effects [34].

The reason for the generally disappointing results for MMP inhibition until now could be the choice of tumor type for clinical studies. In preclinical studies, MMP inhibitors proved to be most effective with renal cell carcinoma and malignant melanoma. No declaration of clinical efficacy has yet been made for these tumor types.

\section{Integrin Antagonists}

Integrin antagonists are currently being tested in several phase I-II studies. One phase I study with Vitaxin ${ }^{\circledR}$ has been completed. Notable response rates were not recorded, however SD could be shown in 3 patients. Circulatory antibodies could be continually measured without toxicity using an i.v. application of the antibody with doses of $2.5-3.5 \mathrm{mg} / \mathrm{kg}$ every 3 weeks [35]. EMD 121974 is currently being tested on patients with anaplastic glioma (phase I/II) and Kaposi's sarcoma (phase I). Early presentations are describing stable diseases under this compound [36]. Another case of SD could only be described in one patient in a phase I study involving patients with various solid tumors. The dose levels ranged up to 800 $\mathrm{mg} / \mathrm{m}^{2}$ twice a week. Changes of soluble TIE-2 (angiopoetin receptor 2) could be observed, suggesting its role as surrogate for EMD 121974. 


\section{Compounds with Unknown Antiangiogenic Mechanism}

Thalidomide, a glutamic acid derivative, is well-known due to its teratogenetic effects, which have been attributed to its antiangiogenic mechanisms. It involves the modulation of various proangiogenic cytokines, e.g. of VEGF and bFGF [37, 38]. Thalidomide is studied in a variety of solid tumors. In certain phase I-III studies SD up to CR could be described at optimal doses of $300 \mathrm{mg} / \mathrm{m}^{2}$. Sedation, thrombosis, and neurologic toxicity represent the main toxicities, especially in higher doses (400-1,200 mg/d) used in earlier trials. In the treatment of refractory or relapsed multiple myeloma, impressive response rates of $30 \%$ could be achieved. In a phase II trial in patients with recurrent high-grade gliomas (final daily dose 1,200 mg) notable response rates could not be observed, but SD was recorded in $33 \%[39,40]$.

IM 862 is an L-glutamyl-L-tryptophan dipeptide which inhibits angiogenesis by immunomodulation. It activates killer cells and has a regulating function on several cytokines, including VEGF. The antiangiogenic effects could be shown in vitro and in animal models [41]. A phase I study on the treatment of patients with AIDS-related Kaposi's sarcoma with IM 862 resulted in a $36 \%$ response (CR, PR) and SD in $48 \%$. Negligible side effects were occasionally reported under the applied dose of $5 \mathrm{mg} / \mathrm{d}$. In one phase II study treating patients with advanced ovarian cancer, a definite response could be recorded in a single patient and SD in several others. IM 862 was applied as intranasal drops and well-tolerated at all dosage levels. The maximum dose was $120 \mathrm{mg} / \mathrm{d}$. Grade III toxicity which could be attributed to IM 862 included nausea, vomiting, and cephalalgia. The MTD is not reached [42]. Further studies are still being carried out, also involving patients with metastatic colorectal carcinomas.

TNP-470, one of the first substances to be recognized to have an antiangiogenic effect, is an analogue of the antibiotic fumagillin. An inhibition of bFGF-induced angiogenesis has been shown in vitro and in vivo. An inhibition of the growth of HUVECs (human umbilical vein endothelial cells) is possible even with low concentrations of TNP-470. The administration of TNP-470 to mice that had received a subcutaneous injection of pancreas tumor cells resulted in a reduction in tumor size and the severity of metastases in comparison to untreated animals [44]. One phase I study with TNP-470 in patients with advanced prostate carcinoma could not show antitumoral efficacy but a stimulation of PSA values in several cases [43]. In another phase I study with patients with cervix carcinoma one patient was recorded with $\mathrm{CR}$, which continued for 8 months after the end of the therapy [45]. A synergetic effect could be observed in combination with carboplatin and paclitaxel, final data on the response rates are not yet available. The main side effects to be observed were neuropsychiatric symptoms, for example ataxia, asthenia, and agitation. The MTD is 71 $\mathrm{mg} / \mathrm{m}^{2}$.

Squalamine, an aminosterol, is an extract of dogfish shark liver. After intracellular uptake it has a direct effect on acti- vated endothelial cells. It inhibits the sodium hydrogen exchanger, blocking mitogen-induced proliferation and migration of endothelial cells. The exact antiangiogenic mechanism, however, is unknown [46]. Only preliminary results of one phase II study are available at present. The study involved patients with chemosensitive NSCLC. Squalamine was applied in combination with carboplatin and paclitaxel. Of 18 patients 27\% showed PR. Unfortunately, the study lacks a monotherapy arm. Data from other studies show response rates of $15-28 \%$ in combined therapy with paclitaxel and carboplatin. The optimum dosage of squalamine has been defined as 300 $\mathrm{mg} / \mathrm{m}^{2} / \mathrm{d}$. Side effects were neutropenia hyponatremia, raised transaminase levels and anemia [47].

The antiangiogenic and antimetastatic effects of carboxyamido-triazol (CAI), a synthetic compound, are attributed to the inhibition of calcium channels, which initiates several signal transduction processes. The influence on angiogenesis is caused by inhibition of VEGF and MMPs. An inhibition of EC proliferation has been shown in vitro [48]. Results of a phase I study with CAI are now available. $1 \mathrm{MR}$ and SD in $47 \%$ of the patients were recorded. Toxicity included ataxia, confusion and gastrointestinal side-effects. The maximum tolerable dose was $350 \mathrm{mg} / \mathrm{m}^{2} / \mathrm{d}$. In another phase I study, CAI was tested in combination with paclitaxel. No additional toxicity could be observed $[49,50]$. CAI is at present being tested in phase II studies.

\section{Old Drugs - New Indication}

There is an increasing trend to proof compounds developed for other indications for their antitumoral or antiangiogenic potency [51]. Some main examples for this kind of development are coming from angiogenesis or proapoptotic research. Metronomic therapy describes the use of low dose continuos chemotherapy to treat proliferating endothelial cells. Different cytotoxic compounds are under clinical development like cyclophosphamide, methotrexate, and capecitabine [52]. A German trial combines metronomic therapy (capecitabine $2 \times$ $1 \mathrm{~g} / \mathrm{m}^{2} / \mathrm{d}$ p.o.) with an anti-inflammatory compound (celecoxib $1 \times 25 \mathrm{mg} / \mathrm{d}$ p.o.) that is also known to be antiangiogenic and an antidiabetic compound (actos $1 \times 45 \mathrm{mg} / \mathrm{d}$ p.o.) that is also known to be proapoptotic [53]. The profile with low side effects and responses in heavily pretreated patients supports the ongoing investigation in known compounds with other indications.

\section{Discussion}

The results of the preclinical studies with antiangiogenic agents had been very promising, often showing partly or complete tumor regression without any drug resistance. However, these results could not be confirmed in clinical trials. Objective tumor responses were achieved only in some cases. Especially the minimal antitumoral effects of endostatin/angio- 
statin in doses equivalent to those used in animal models has been disappointing. VEGF receptor tyrosine kinase inhibitors like PTK787/ZK22254 or thalidomide might actually be the most promising substances for some tumor entities.

The differing response rates to an angiogenic drug among patients might be explained by their different angiogenic phenotypes. The regulation of angiogenesis in humans is obviously much more complex than previously thought. It must be presumed that neovascularization is controlled by the combined effects of several factors with different mechanisms. New receptor/ligand systems are increasingly being described and could be further important regulators of angiogenesis.

It should be mentioned that the proper end-points of studies on antiangiogenic compounds may have to differ from those of standard chemotherapy agents. The success of conventional chemotherapies is measured by objective response rates. Improved survival or duration of stable disease may be more appropriate end-points for antiangiogenic substances. From current trials, surrogate markers like dceMRI and soluble angiogenesis markers turn out to be most predictive for biological activity, defining optimal doses below the MTD.

The combination of angiogenesis inhibitors with cytotoxic chemotherapy may play an important role in the future. The reasoning for this combination is the assumption that the various mechanisms of action and various targets could lead to additive antitumoral effects. Fewer side effects are to be expected than in a classic polychemotherapy. At present it is not clear whether a combination of an angiogenesis inhibitor with chemotherapy will yield an advantage.

The ability to avoid acquired drug resistance is regarded to be one of the advantages of antiangiogenic drugs over other forms of anticancer therapy because of the nature of their cellular target: genetically stable endothelial cells rather than rapidly mutating, genetically unstable cancer cells. Recently there is accumulating preclinical and clinical evidence that a number of antiangiogenic drugs or strategies can lose their activity over time. This could be caused by several possible mechanisms, e.g. an overexpression of other proangiogenic factors that may antagonize the function of the antiangiogenic agents if only one such factor is the target of an antiangiogenic therapy. For this reason the combined application of angiogenesis inhibitors might be a promising strategy. Inhibition of various receptor/ligand systems could be effective due to the different mechanisms of action within the angiogenesis process. Preliminary in-vitro data describe an increased effect when two angiogenesis inhibitors are applied in combination [51]. In addition, application of antiangiogenic drugs in an adjuvant setting might be another option. Results from clinical studies are not yet available.

The inhibition of angiogenesis still presents an attractive possibility for treating cancer but further preclinical and clinical studies are necessary in order to define an effective application for this form of therapy.

\section{References}

1 Marme D: Tumor Angiogenesis: The pivotal role of vascular endothelial growth factor. World J Urol 1996;14:166-174.

2 Drevs J, Hofmann I, Hugenschmidt H, Wittig C, Madjar H, Muller M, Wood J, Martiny-Baron G, Unger C, Marme D: Effects of PTK787/ZK222584, a specific inhibitor of vascular endothelial growth factor receptor tyrosine kinases, on primary tumor, metastasis, vessel density, and blood flow in a murine renal cell carcinoma model. Cancer Res 2000;60:4819-4824.

3 Fong TA, Shawver LK, Sun L,Tang C, App H, Rowell TJ, Kim YH, Mc Mahon G: SU 5416 is a potent and selective inhibitor of the vascularization, and growth of multiple tumor types. Cancer Res 1999;59:99-106.

4 Stopeck A: Results of a phase I dose-escalating study of the antiangiogenic agent, SU 5416, in patients with advanced malignancies. Proc ASCO 2000;19:802.

5 Britten C, Rosen L, Kabbinavar F, Rosen P, Mulay M, Hernandez L: Phase I trial of SU6668, a small molecule receptor tyrosine kinase inhibitor, given twice daily in patients with advanced cancers. Proc ASCO 2002;21:28b.

6 Drevs J, Esser N, Marme D: Effect of ZD6474, a VEGF receptor tyrosine kinase inhibitor, on primary tumor growth, metastasis and vessel density in murine renal cell carcinoma. Proc AACR 2002; 43:1082.

7 OReilly MS: Angiostatin: An endogenous inhibitor of angiogenesis and of tumor growth. EXS 1997; 79:273-294.
8 Kim YM, Jang JW, Lee OH, Yeon J, Choi EY, Kom KW, Lee ST, Kwon YG: Endostatin inhibits endothelial and tumor cellular invasion by blocking the activation and catalytic activity of matrix metalloproteinase. Cancer Res 2000;60:5410-5413.

9 Miao WM, Seng WL, Duquette M, Lawler P, Laus C, Lawler J: Thrombospondin-1 type 1 repeat recombinant proteins inhibit tumor growth through transforming growth factor- $\beta$ dependent and independent mechanisms. Cancer Res 2001;61:78307839.

10 Hidalgo M, Eckhardt SG: Development of matrix metalloproteinase inhibitors in cancer therapy. J Natl Cancer Inst 2001;93:178-193.

11 Santos O, McDermott CD, Daniels RG, Appelt K: Rodent pharmacokinetic and anti-tumor efficacy studies with a series of synthetic inhibitors of matrix metalloproteinases. Clin Exp Metastasis 1997;15:499-508.

12 Brown PD: Ongoing trials with matrix metalloproteinase inhibitors. Expert Opin Investig Drugs 2000;9:2167-2177.

13 Kumar CC, Malkowski M, Yin Z, Tanghetti E, Yaremko B, Nechuta T, Varner J, Liu M, Smith EM, Neustadt B, Presta M, Armstrong L: Inhibition of angiogenesis and tumor growth by SCH221153, a dual alpha v beta 3 and alpha v beta 5 integrin receptor antagonist. Cancer Res 2001; 61:2232-2238.

14 Kirsch M, Santarius T, Black PM, Schackert G: Therapeutic anti-angiogenesis for malignant brain tumors. Onkologie 2001;24:423-430.
15 MacDonald TJ, Taga T, Shimada H, Tabrizi P, Zlokovic BV, Cheresh DA, Laug WE: Preferential susceptibility of brain tumors to the antiangiogenic effects of an alpha (v) integrin antagonist. Neurosurg 2001;48:151-157.

16 Drevs J, Schmidt-Gersbach C, Mross K, Medinger M, Müller M, Steward W, Laurent D, Dugan M, Lee L, Henry A, Marmé D, Unger C: Surrogate markers for the assessment of biological activity of the VEGF-receptor inhibitor PTK787/ZK 222584 (PTK/ZK) in two clinical phase I trials. Proc ASCO 2002;21:85a.

17 Lara P, Quinn D, Margolin K, Meyers F, Longmate J, Frankel P, Turell C, Valk P, Rao J, Buckley P, Doroshow J, Gandara D: Angiogenesis inhibition in RCC: A phase II California Cancer Consortium study of SU5416 + interferon with biologic und imaging correlates. Proc ASCO 2002;21:185a

18 Tolcher A, Karp D, O'Leary J, DeBono J, Caulkins JD, Molpus K, Sutula K, Ferrante KJ, Gualberto A, Noe DA, Hubermann M, Rowinsky EK, Healy D: A phase I and biologic correlative study of an oral vascular endothelial growth factor receptor-2 (VEGFR-2) tyrosine kinase inhibitor, CP-547 632, in patients (pts) with advanced solid tumors. Proc ASCO 2002;21:334a.

19 Basser R, Hurwitz H, Barge A, Davis I, DeBoer R, Holden S, McArthur G, McKinley M, Nairn K, Persky M, Rosenthal M, Swaisland H, Eckhardt G: Phase 1 pharmacokinetic and biological study of the angio-genesis inhibitor ZD6474, in patients with solid tumors. Proc ASCO 2001;20:100a. 
20 Jones-Bolin S, Hunter K, Zhao H, Ruggeri B: The effects of the orally-active VEGF-R kinase inhibitor, CEP-7055, on primary tumor growth and metastatic profile in orthotopic models of human pancreatic ductal carcinoma and murine renal carcinoma (RENCA) in mice. Proc AACR 2002; 43:2601a.

21 Langmuir V, Cobleigh M, Herbst R, Holmgren E, Hurwitz H, Kabbinavar F: Successful long-term therapy with bevacizumab (Avastin) in solid tumors. Proc ASCO 2002;21:9a.

22 Posey J, Ng T, Yang B, Khazaeli M, Fox F, Engel J: A phase I trial of an anti-KDR (VEGFR) chimeric antibody in patients with liver metastases in colorectal cancer. Proc ASCO 2002;21:17a.

23 Herbst RS, Tran HT, Mullani NA, Charnsangavej C, Madden TL, Hess KR, Davis D, McConkey, DJ, Baker C, O’Reilly M, Ellis LM, Kim E, Bucana C, Lee AT, Roach JS, Terry KA, Gravel DM, Dourado JE, Pluda JM, Fidler IJ, Hong W, Abrruzzese JL: Phase I clinical trial of recombinant human Endostatin in Patients with Solid Tumors: Pharmacokinetic, Safety and Efficacy Analysis Using surrogate endpoints of tissue and radiologic response. Proc ASCO 2001;20:3a.

24 DeMoraes ED, Fogler WE, Grant D, Wahl M, Leeper D, Zrada S,Malin A, Connors S, Fortier AH, Dabrow M, Sidor C, Capizzi RL: Recombinant human angiostatin: A phase I clinical trial assessing safety, pharmacokinetics and pharmacodynamics. Proc ASCO 2001;20:3a.

25 Eder J, Clark J, Supko J, Garcia-Carboreo R, Ryan D, Shulman L: A phase I trial of recombinant human endostatin. Proc ASCO 2002;21:81a.

26 Hansma A, Hoekman K, Broxterman H, Kievit E, Horst I, Bove E: A phase I study of rhEndostatin: continous intravenous followed by subcutaneous administration. Proc ASCO 2002;21:21a.

27 Fielding J, Scholefield J, Stuart R, Hawkins R, McCulloch P, Maughan T, Seymour M, Van Cutsem E, Thorlacius-Ussing O, Hovendal C: A randomized double-blind placebo controlled study of marimastat in patients of marimastat in patients with inoperable gastric adenocarcinoma. Proc ASCO 2000;19:929.

28 Wolff AC, Krishnamurthi S, Sparano JA, Armstrong DK, Davidson NE, Fetting MH, DeClue C, Bowling MK, Sarta C, Donehower RC, Baker SD: A pharmacokinetic $(\mathrm{PK})$ and pharmacodynamic study of doxorubicin and docetaxel combinations plus marimastat in metastatic breast cancer. Proc ASCO 2001;20:98a.

29 Rugo, HS, Budman D, Vogel C, Baidas S, Fleming G, Collier M, Dixon M, Pithavala Y, Cleneninn NJ, Tripathy D, Hayes D: Phase II study of the matrix metalloproteinase inhibitor prinomastat in patients with progressive breast cancer. Proc ASCO 2001; 20:48a.

30 Smylie M, Mercier R, Aboulafia D, Tucker R, Bonomi P, Collier M, Keller M, Stuart-Smith J, Knowles M, Clendeninn NJ, Shepherd F: Phase III study of the matrix metalloprotease inhibitor prinomastat in patients having advanced non-smallcell-lung-cancer. Proc ASCO 2001;20:307.
31 Ahmann FR, Saad F, Mercier R, Huddart RA, Roberts JT, Collier M, Bettencourt L, Zhang MH, Clendeninn NJ, Wilding G: Interim results of a phase III study of the matrix metallo-protease inhibitor prinomastat in patients having metastatic, hormone refractory prostate cancer. Proc ASCO 2001;20:174b.

32 Hurwitz J, Humphrey K, Williams K, Ness E, Conway A, Lockhart A, Bielefield M, Tarby C, Sonnochsen D, Gupta E, Huang M, Mao Y, Raphael M, Daley D, Marshall J, Johnson M, Rizvi N: A phase I trial of BMS-275291: A novel, non-hydroxamate, sheddase-sparing matrix metalloproteinase inhibitor with no dose-limiting arthritis. Proc ASCO 2001;20:98a.

33 Rudek MA, Figg WD, Dyer V, Kahut W, Turner ML, Steinberg SM, Liewehr DJ, Kohler DR, Pluda JM, Reed E: Phase I clinical trial of oral COL-3, a matrix-metalloproteinase inhibitor, in patients with refractory metastatic cancer. J Clin Oncol 2001;19: 584-592.

34 Batist G, Champagne P, Hariton C, Dupont E: Dose-survival relationship in a phase II study of neovastat in refractory renal cell carcinoma patients. Proc ASCO 2002;21:1907a.

35 Posey JA, Khazaeli MB, DelGrosso A, Saleh MN, Lin CY, Huse W, LoBuglio AF: A pilot trial of Vitaxin, a humanized anti-vitronectin receptor antibody in patients with metastatic cancer. Cancer Biother Radiopharm 2001;16:125-132.

36 Eskens R, Dumez H, Verwej J, Perschl A, Kovar A, Brindley C, van Oosterom A: Phase I and pharmacologic study of EMD 121974, an alpha v beta 3 and alpha v beta 5 integrin inhibitor that perturbs tumor angiogenesis, in patients with solid tumors. Proc ASCO 2000;19:206a.

37 Belo AV, Ferreira MA, Bosco AA, Machado RD, Andrade SP: Differential effects of thalidomide on angiogenesis and tumor growth in mice. Inflammation 2001;25:91-96.

38 Moreira AL, Friedlander DR, Shif B, Kaplan G, Zagzag D: Thalidomide and a thalidomide analogue inhibit endothelial cell proliferation in vitro. J Neurooncol 1999;43:109-114.

39 Rajkumar SV: Thalidomide in multiple myeloma. Oncology 2000;14:11-16.

40 Schwartz J, Sung M, Lehrer D, Goldenberg A, Muggia F, Volm M: Thalidomide for unresectable hepatocellular cancer (HCC) with optional interferon-alpha upon disease progression. Proc ASCO 2002;21:21a.

41 Garcia A, Gordon A, Markman M, Lele S, Khayrallah M, Klein K: Phase I/II trial of IM 862, a novel immunomodulator with anti-angiogenic activity, in patients with recurrent ovaran cancer. Proc ASCO 2001;20:211a.

42 Tulpule A, Scadden DT, Espina BM, Carbiales S, Howard W, Shea K, Gill PS: Results of a randomized study of IM 862 nasal solution in the treatment of AIDS-related Kaposi's sarcoma. J Clin Oncol 2000;18:716-723.
43 Logothetis CJ, Wu KK, Finn LD, Daliani D, Figg W, Ghaddar H, Gutterman JR: Phase I trial of the angiogenesis inhibitor TNP-470 for progressive androgen-independent prostate cancer. Clin Cancer Res 2001;7:1198-1203.

44 Hotz HG, Reber HA, Sanghavi PC, Yu T, Foitzik T, Buhr HJ, Hines OF: Angiogenesis inhibitor tnp-470 reduces human pancreatic cancer growth. J Gastrointest Surg 2001:5:131-138.

45 Kudelka AP, Verschraegen CF, Loyer E: Complete remission of metastatic cervical cancer with the angiogenesis inhibitor TNP-470. N Engl J Med 1998; 338:991-992.

46 Schiller JH, Hammond LA, Carbone DP, Hong WK, Holroyd K, Williams JI, Hait H, Rowinsky EK, Herbst RS: Hase 2A trial of squalamine for treatment of advanced non-small cell lung cancer. Proc ASCO 2001;20:339a.

47 Williams JI, Weitman S, Gonzalez CM, Jundt CH, Marty J, Stinger SD, Holdroyd DK, Mclane MP Chen Q, Zasloff M, von Hoff DD: Squalamine treatment of human tumors in $\mathrm{nu} / \mathrm{nu}$ mice enhances platinum-based chemotherapies. Clin Cancer Res 2001:7:7224-7233.

48 Ge H, Rempel SA, Divine G, Mikkelsen T: Carboxyamido-triazole induces apoptosis in bovine aortic endothelial and human glioma cells. Clin Cancer Res 2000;6:1248-1254.

49 Berlin J, Tutsch KD, Hutson P, Cleary J, Rago RP, Feierabend C,Wilding G: Phase I clinical and pharmacokinetic study of oral carboxy-amidotriazole, a signal transduction inhibitor. J Clin Oncol 1997;15: 781-789.

50 Kohn EC, Reed E, Sarosy GA, Minasian L, Bauer KS, Bostick-Bruton F, Kulpa V, Fuse E, Tompkins A Noone M, Goldspiel B, Pluda J, Figg WD Liotta LA: A phase I trial of carboxyamido-triazole and paclitaxel for relapsed solid tumors: Potential efficacy of the combination and demonstration of pharmacokinetic interaction. Clin Cancer Res 2001;7:1600-1609.

51 Klement G, Baruchel S, Rak J, Mam S, Clark K, Bohlen P, Kerbel RS: Continuous low-dose therapy with vinblastine and VEGF receptor-2 antibody in duces sustained tumor regression without overt toxicity. J Clin Invest 2000;105:15-24.

52 Colleoni M, Rocca A, Sandri MT, Zorzino L, Masci G, Nole F: Low-dose oral methotrexate and cyclophosphamide in metastatic breast cancer: Antitumor activity and correlation with vascular endothelial growth factor levels. Ann Oncol 2002;13(1):73-80.

53 Reichle A, Bross K, Vogt T, Bataille F, Wild P, Wodzynski A, Zaiss M, Wagner H, Klebl F, Messmann H, Krause S, Dengler R and Andreesen R: Pioglitazone and rofecoxib combined with angiostatic scheduling of chemotherapy in far advanced malignancies. Proc ASCO 2002;21:6a. 